\title{
Comparative study of suture and cyanoacrylates in skin closure of rats ${ }^{1}$
}

\author{
Estudo comparativo entre sutura e cianoacrilatos no fechamento de pele de ratos
}

\author{
Sandro Cilindro de Souza ${ }^{2}$, Washington Luiz de Oliveira ${ }^{3}$, Dario Fernando de Oliveira Santos Soares ${ }^{3}$, Carlos \\ Henrique Briglia ${ }^{4}$, Paulo Roberto Athanázio ${ }^{5}$, Martins Dias de Cerqueira ${ }^{6}$, Pedro Hamilton Guimarães ${ }^{7}$, Mário \\ Castro Carreiro ${ }^{7}$
}

1. Research performed at Experimental Research Centre (NUPE), Faculty of Medicine of Bahia (FAMEB), Federal University of Bahia (UFBA), Salvador - Bahia, Brazil.

2. Surgeon, Northeast's Adventist Education Institute, Capoeiruçu - Bahia, Brazil.

3. Graduate Student, FAMEB, UFBA, Salvador, Brazil.

4. Surgeon, Bahia's General Hospital, Salvador - Bahia, Brazil.

5. Master in Pathology, Prof. Edgar Santos University Hospital, UFBA, Salvador - Bahia, Brazil.

6. Master in Chemistry, Chemistry Institute, UFBA, Salvador - Bahia, Brazil.

7. Associate Professor, Surgery Department, FAMEB, UFBA, Salvador - Bahia, Brazil.

\begin{abstract}
Purpose: To compare the biocompatibility of ethyl-cyanoacrylate (ECA) and octylcyanoacrylate (OCA) wound closures to sutures in rat skin. Methods: Twenty-four male Wistar rats were subjected to three incisions which were closed using ECA, OCA or sutures . Rats were divided into four groups which received biopsies on the $3^{\text {rd }}, 7^{\text {th }}, 14^{\text {th }}$ or $21^{\text {st }}$ postoperative days. Necrosis, inflammation, dermatitis, infection, dehiscence, cicatricial enlargement and costs were examined; the histopathology evaluated was epithelialization, deep openings, foreign substance reaction, residues of synthesis material, fibrosis, inflammation, dehiscence and necrosis. Results: The tissue adhesives presented the largest dehiscence levels, and ECA the lowest cost while the other measures were similar. Regarding histopathology, deep openings were more common with OCA and granulomas were most frequently obtained with ECA. The two tissue adhesives produces less inflammation than the inicial suture from post-operative day 7, while ECA and OCA cause similar inflammatory reactions. ECA did not differ significantly from OCA and sutures on other measures. Conclusion: ECA was well tolerated in this study and did not induce necrosis, allergic reactions or infections, presenting several advantages in relation to OCA and sutures, including lower costs and fewer complications.
\end{abstract}

Key words: Tissue adhesives. Cyanoacrylates. Materials Testing. Rats.

\section{RESUMO}

Objetivo: Investigar a biocompatibilidade do etil-cianoacrilato (ECA) em fechamento de pele em ratos comparativamente ao octil-cianoacrilato (OCA) e à sutura. Métodos: Rattus norvegicus albinus $(\mathrm{n}=24)$ foram submetidos a três incisões, cada uma fechada por um dos métodos de síntese estudados. Quatro grupos $(\mathrm{n}=6)$ foram feitos, conforme o dia pósoperatório (DPO) em que foram eutanasiados: 3DPO, 7DPO,14DPO e 21DPO. Necrose, edema, eritema, dermatite, infecção, deiscência, alargamento cicatricial e custos foram os itens examinados; histopatologicamente avaliou-se epitelização, abertura profunda, reação de corpo estranho, resíduos de material de síntese, fibrose, reação inflamatória, deiscência e necrose. Resultados: Os adesivos apresentaram os maiores níveis de deiscências, e o ECA o custo mais baixo; nos demais itens, não houve diferenças. Histopatologia: A abertura profunda foi mais comum com o OCA; ECA foi o material mais encontrado em granulomas; os adesivos foram mais brandos que a sutura a partir do $7^{\circ} \mathrm{DPO}$ no quesito inflamação, enquanto que o ECA causou uma reação similar ao OCA; nos outros itens, ECA não apresentou diferença importante em relação ao OCA e à sutura. Conclusão: O ECA foi bem tolerado neste grupo de estudo, sem induzir necrose, reações alérgicas e infecção, apresentando diversas vantagens de uso em relação ao OCA e à sutura.

Descritores: Adesivos Teciduais. Cianoacrilatos. Teste de Materiais. Ratos. 


\section{Introduction}

Tissue adhesives are substances that self-polymerize to join the edges of an injury and aid its cicatrisation. They constitute an alternative to automatic synthetic methods such as suturing. Beyond this, they do not promote tissue trauma and they eliminate the need to remove stitches. The ideal adhesive must provide adequate tensile strength against biological fluids and keep tissues joined until the proper cicatrisation occurs, but it should not alter immune system function in the wound. Furthermore, it should be biodegradable, nontoxic, readily available and quick drying ${ }^{2,3}$. Since the end of the 1950's, synthetic adhesives have been used in medical applications ${ }^{4}$. One type of such adhesive is the cyanoacrilates (CA) which are currently the most commonly used adhesives for cutaneous closings, especially the 2-butyl-cyanoacrilate (BCA) and 2-octilcyanoacrilate (OCA) forms. In a spontaneous exothermic reaction, these substances self-polymerize by ester cyanoacrilic monomerous $\mathrm{CH} 2=\mathrm{C}(\mathrm{CN}) \mathrm{COOR}$ spreading. The resulting pellicle joins the adhesives like a bridge. The most important chemical characteristic of CAs is the capacity to form a quick, strong bond that progressively increases in intensity over the following $48 \mathrm{~h}^{5,6}$. The advantages of CA in cutaneous synthesis are widely described in the literature ${ }^{7}$, however, these products have been underutilized in Brazil due to high costs $^{6}$. Moreover, the most accessible CA form is 2-ethyl cyanoacrilate $^{4}$ (ECA), which has been not widely studied in terms of tolerance, histological reactions in different cicatrisation phases and capacity to avoid dehiscence ${ }^{6,8-}$ ${ }^{11}$. Low income patients, who constitute a large portion of the population attending public hospitals, have been deprived of CAs' benefits due to the high costs of the CA form approved for human use. One type of CA that has been considered a relatively good solution for wound closure in relation to other CAs and sutures ${ }^{6,8,10}$ is ECA. It has been used satisfactorily in clinical procedures involving odontology, abdominal surgery, gynecology, gastrology, neurological surgery, maxillary surgery, orthopedics, plastic surgery, urology, vascular surgery, cardiac surgery, thoracic surgery, and legal medicine ${ }^{4,12-}$ ${ }^{15}$. Furthermore, ECA is not carcinogenic ${ }^{11}$, while another CA type metil cyanoacrilat monomerous (MCA, Eastman monomerous) in large doses caused sarcoma development in rats ${ }^{16}$. The present study compares the biocompatibility of ECAs and OCAs to that of sutures in an experimental model.

\section{Methods}

Twenty four male Wistar rats (250-300 g) were acclimated in individuals cages with for 14 days with a 12 / 12 light / dark cycle and received food and water ad libitum. Rats were anesthetized with ketamine hydrochloride (100 mg/Kg, i.p.) and tyaside hydrochloride (20 mg/Kg, i.p.). They were put in a ventral decubitus with legs secured to a surgical plate. A rectangular area of $9 \mathrm{~cm} \mathrm{x} 7 \mathrm{~cm}$ in the dorsal central region of the back was trichotomised manually. Antiasepsis was achieved with $2 \%$ iodine alcohol solution followed by placement of discarded sterile fields. Three longitudinal incisions (two on the left and one on the right) were made 1 to $1.5 \mathrm{~cm}$ from the mid-line in the trichotomised area and were guided by a standard model; left cuts were separated by $4 \mathrm{~cm}$. A scalpel with blade 15 was used to entirely penetrate the skin. Hemostasia was achieved by manual compression with gauze for about 2 minutes. Each of the 3 cuts received one kind of closure, either suture, ECA or OCA. The methods were distributed equally amongst the cut positions. Sutures were made with three simple nylon 5-0 stitches; deep relaxing sutures were used. Two successive drops of adhesive were put on the respective incisions to form two thin superimposed films; one minute was allotted to polymerize each pellicle. The products were not permitted escape onto the rat to prevent damage. Digital photographs were taken for macroscopic comparison. Next, the animals were randomly distributed into four groups according to the post-operative day on which biopsies were performed, either $3,7,14$ or $21 \mathrm{~d}$ after surgery. On the $7^{\text {th }}$ day the stitches were removed (Figure 1). Post-operative monitoring entailed noting the development of: 1) necrosis - darkening and cutaneous scab of an ulcer; 2) inflammation - edema or erythema continuous with the incision edges; 3 ) contact dermatitis - spots, plates or erythemathosus papule, phlyctena or erythema formation in non-continuous or distant edges of the incision; 4) infection - presence of purulent secretion or abscess; 5) dehiscence - distance $>1 \mathrm{~mm}$ from the skin edges; and 6) fibrosis - widening of the scar by $>1 \mathrm{~mm}$ over at least half of its length. For biopsy, animals were euthanized by carbon dioxide inhalation and a $2.5 \mathrm{~cm} \times 1.0 \mathrm{~cm}$ rectangle that contained the incisions was resected. Samples were kept in $10 \%$ formaldehyde and coded for pathological screening before blocking in paraffin. Sections were cut $(6 \mathrm{~cm})$ on a microtome, including the scar middle and stained with picrosirius and hematoxylin-eosin (HE). Quarantine fields were visualized in each cut and they were evaluated with optics microscopy for epithelization, inflammation (acute, chronic and granulomathose), fibrosis, dehiscence, deep opening, residues of materials and necrosis. Observations were done blind by the same pathologist on three separate occasions. Data were analyzed using descriptive statistics. 


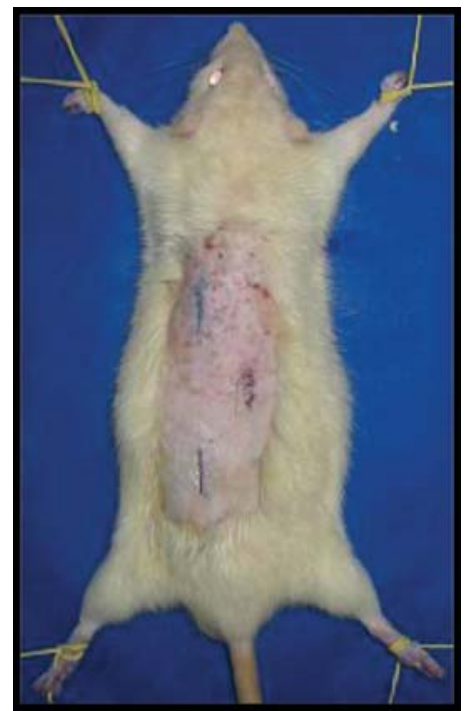

FIGURE 1 - Comparison of incision closures with sutures (on the right), ECA (superior- left) and OCA (inferior-left)

\section{Results}

\section{Clinical evaluation}

Two rats died (83\%) within the first $24 \mathrm{~h}$ after the surgery; necropsies were performed but the causa mortis could not be identified in either case. In wounds with ECA closing, 5 showed dehiscence, two on the $3^{\text {rd }}$ POD and three on the $7^{\text {th }}$ POD; these could not be visualized in the following periods. Two of the OCA closings presented dehiscence, both on the $3^{\text {rd }}$ POD. No evidence of infection, necrosis, allergies/inflammation, scar widening or fibrosis was apparent.

\section{Histopathological evaluation}

The following histopathological descriptions are made in order beginning with the elements that presented most frequently. The $3^{\text {rd }}$ and $7^{\text {th }}$ POD's were considered to be within the initial period and the $14^{\text {th }}$ and $21^{\text {st }}$ POD's the end period.

\section{Epithelization}

Epithelization rate on the $3^{\text {rd }}$ POD was 20\% lower than the other PODs. Complete closing of the epidermis was infrequent and a wide empty space was observed between the incision edges. On the $7^{\text {th }}$ POD, epithelization increased considerably by 83,50 and $67 \%$ for the ECA, OCA, and suture closings, respectively. All wounds developed epithelization by the $14^{\text {th }}$ POD (Figure 2).

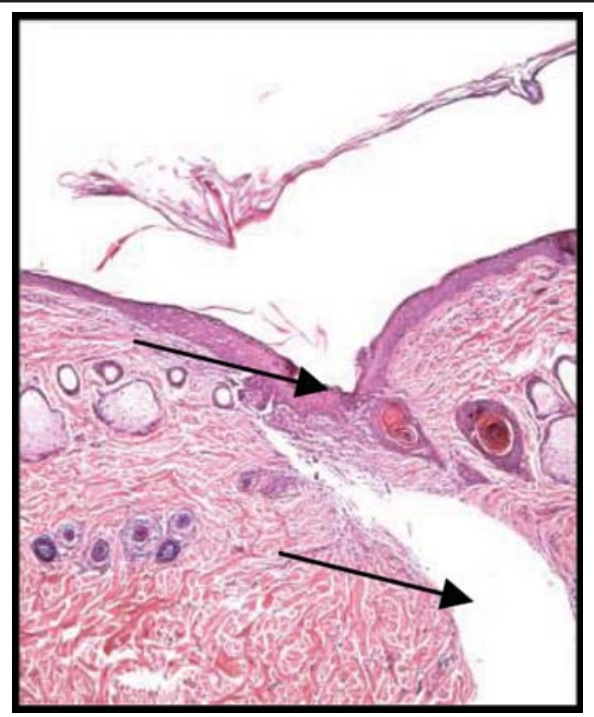

FIGURE 2 - Following wound closure with ECA ( $7^{\text {th }}$ POD), superficial epidermis is closed (top arrow), while a deeper cavity remains (bottom arrow) (200x)

\section{Deep openings}

As shown in Figure 2, the deep opening profile was triangular with the apex turned up in contact with the epidermis; the triangle was filled in the initial periods by an empty space while in the end it was filled by fibrous tissues. On first examination, deep openings were frequent especially with OCA (80\%) and suture (60\%) closings, while ECA was 40\%. Generally higher levels were seen on the $7^{\text {th }}$ POD with all of the OCA closings having deep openings; those for ECA (87\%) and suture (50\%) were lower. Deep opening frequency decreased on the $14^{\text {th }}$ and $21^{\text {st }}$ POD's (ECA $-40 \%$ and $17 \%$, OCA - $20 \%$ and $87 \%$ and suture $20 \%$ and $17 \%$ ), except the dehiscence peak on the $21^{\text {st }}$ POD for the OCA closings (87\%). In all, the worst result periods were presented by the adhesives, especially OCA.

\section{Reactions to foreign substances in the wound}

Formations achieved with ECA on the $3^{\text {rd }}$ POD, OCA on the $7^{\text {th }}$ POD and suture on the $14^{\text {th }}$ POD presented the highest percentages of reactions to foreign substances (100, 67 and $100 \%$, respectively). On the $3^{\text {rd }}$ POD the reactions were less frequent in the OCA closings (20\%) and absent in the suture condition. Adhesives caused more reactions than sutures in all periods examined, apart from $14^{\text {th }}$ POD on which all sutures had reactions; at this time ECA was $60 \%$ and OCA was $40 \%$; Figure 3). 


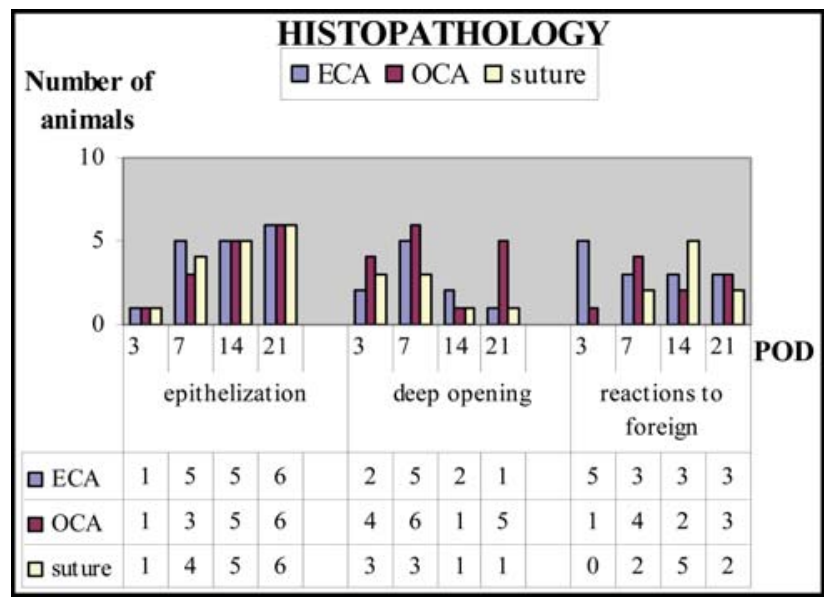

FIGURE 3 - Summary of epithelization histopathological results, deep opening and reactions to foreign substances.

\section{Material residues}

Generally, ECA closings presented high amounts of material inside the formation of abnormal multi-nucleus somatic cells: 60, 67, 60 and 50\% for PODs 3, 7, 14 and 21, respectively. Comparatively, less material residues were seen in suture closings at each POD except for 14 which was $100 \%$; the OCA presented intermediate results (20, 67, 20 and 34\% for ascending PODs; Figure 4).

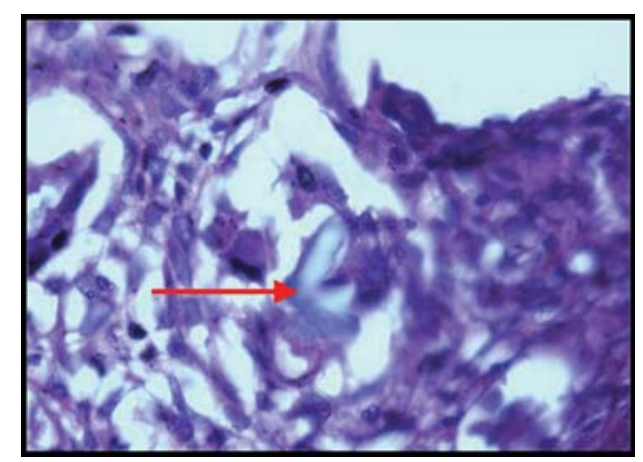

FIGURE 4 - Adhesive fragment in granuloma in wound closed by ECA, $7^{\text {th }}$ POD $(1000 x)$

\section{Fibrosis}

As shown in Figures 5 and 6, fibrosis was not seen on the $3^{\text {rd }}$ POD and was only seen on $7^{\text {th }}$ POD in the ECA closings (17\%). All closing methods showed similarly high incidences of fibrosis in the final periods, especially sutures in which $100 \%$ presented on PODs 14 and 21 compared to ECA with 100 and 67\%, and OCA with 40 and $100 \%$, respectively.

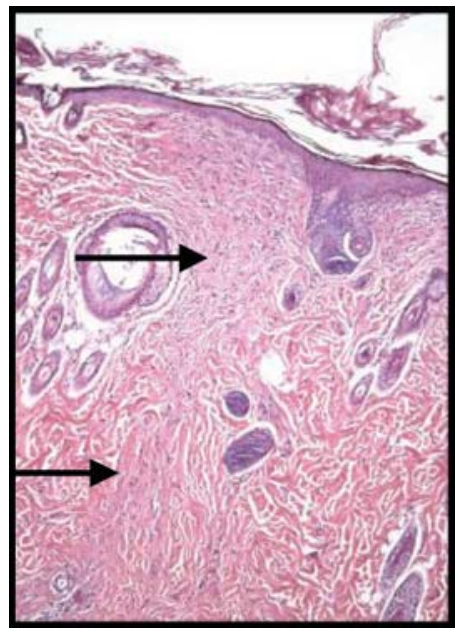

FIGURE 5 - Fibrosis was apparent in the sutured wound on the 21st POD (200x)

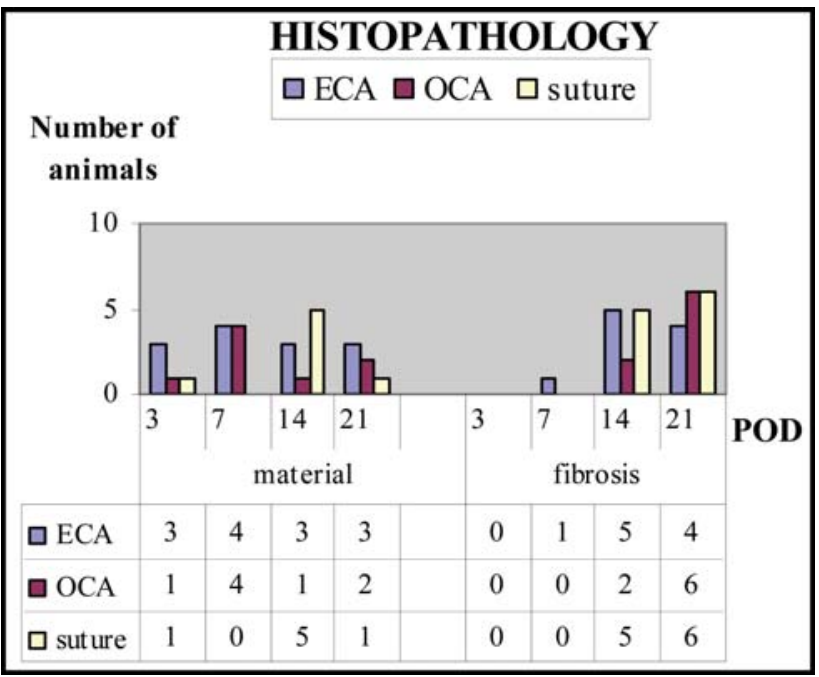

FIGURE 6 - Summary of results of histopathological residues and fibrosis materials.

\section{Inflammation}

Acute and chronic inflammatory reactions were present only in the initial periods, especially on the $3^{\text {rd }}$ POD. At this time, acute inflammation was higher in all groups than the other PODs but was larger in the ECA and OCA closings than with sutures $(80,100$, and XX\%, respectively). However, after the $3^{\text {rd }} \mathrm{POD}$, inflammation, whether acute or chronic, was absent from the adhesive groups. On the $7^{\text {th }}$ POD, inflammation was verified only in suture closings. Chronic inflammation was observed in closings with ECA on the $3^{\text {rd }}$ POD (33\%) and sutures at PODs 3 and 7 (20 and 17\%, respectively), but not OCA (Figure 7). 


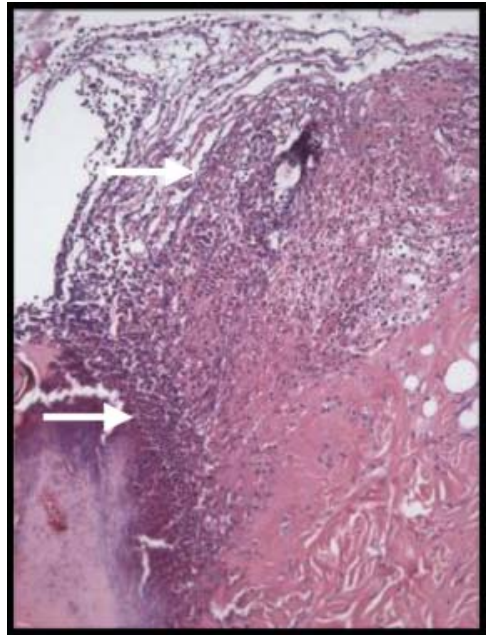

FIGURE 7 - Acute and chronic inflammatory reaction in wound closed by ECA, 3rd POD (200x)

\section{Dehiscence and necrosis}

Wound opening was observed in the initial periods in all groups, but on the $3^{\text {rd }}$ POD, the OCA presented high dehiscence values for all groups were: ECA - 20 and 17\%; OCA - 40 and $17 \%$; suture -2 and $17 \%$, for PODs 3 and 7 , respectively. In the final periods, dehiscence was not observed with any of the closure methods (Figures 8 and 9). Necrosis did not occur at any time point in any of the closings, regardless of the method used.

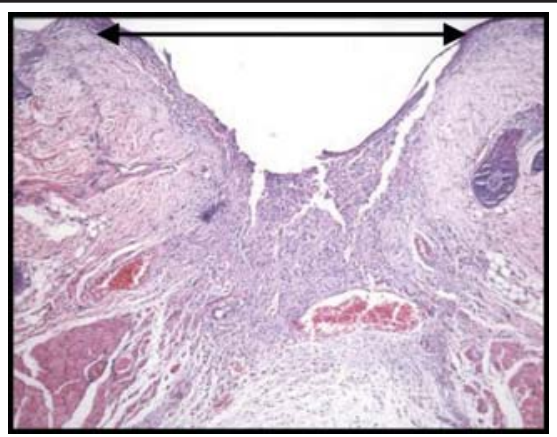

FIGURE 8 - Dehiscence of wound closed by ECA, 7th POD,(200x)

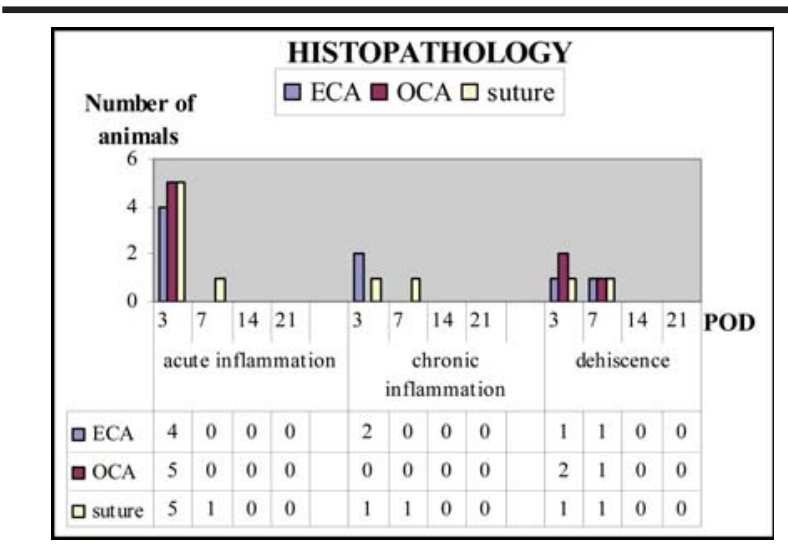

FIGURE 9 - Histopathological results of inflammatory reactions and dehiscence.

\section{Discussion}

Studies comparing the biocompatibility of ECA to BCA, MCA or gelatin adhesives on skin, using silk or nylon sutures as controls yielded promising results ${ }^{6,8,10}$. Thus, we based the present experiments on their methodologies with some modifications to more directly evaluate our objectives. Our adjustments included (1) the use of rats as an experimental model since they afforded ease of use, due to their small size, and care as well as suiting the NUPE-UFBA's experience in their care, (2) the use of OCA instead of BCA because it is more widely used in our area, (3) more clinical and histological features related to cicatrisation were examined, (4) the incisions were dorsal to avoid closing precocious removal materials by the rodent, (5) three cuts were made in the same animal to reduce the quantity of sacrificed animals and to allow within animal comparisons and eliminate between animal variability, (6) the incisions were put distant enough to the cicatrisation so that they did not interfere with each other, (7) to eliminate the effect of the position of the cut the closure type was evenly distributed throughout positions, (8) the observation periods were chosen according to initial phases ( 3 and 7 days) and the final period (14 and 21), which is most critical to cicatrisation complications, (9) the incisions were removed in monoblocks which provide a sufficient quantity of tissue for microscopic analyses, (10) histological examination was performed in the incision center, where most phenomenon occurred, and (11) HE staining enabled global microscopic evaluation while the picrocirius specifically visualized fibrosis. Acute and chronic inflammation ${ }^{5}$, seroma, necrosis and bony graft extrusion ${ }^{11}$, cytotoxity in vitro ${ }^{12,17}$, skin necrosis ${ }^{18}$, leuconiquia ${ }^{19}$, contact dermatitis ${ }^{20}$ and aneurism in anomalous cerebral artery ${ }^{21}$ have been problems that the literature attributes to ECA use. These problems have made difficult to accept for wide use. In spite of the possible complications, many authors have considered ECA a safe bio-adhesive for use in vivo due to the qualities it shares with the other CAs such as its resistance to exuded actions, the ability to support up to a traction of $500 \mathrm{~g}$, fast polymerization, provisory toxicity and related effects, bactericide and hemostatic effects when applied to the wound ${ }^{2,6,12}$. Furthermore, many studies have suggested a more widespread use of ECA over other CAs due to its low cost, fast degradation and ample disposability ${ }^{4,8,14,15}$. These suggestions have prompted many professionals to use the derivative short chain as ECA in their clinical practice, in spite of the disposability of other products supposing that they are less toxic ${ }^{11}$. This study showed that the CA's substantially facilitated wound closure. Once polymerized, the CAs formed a flexible, strong and fluid-resistant covering on the wound which eliminated the need to use stitches and 
needles. This eradicated puncture accidents, reduced the amount of care monitoring and the use of anesthetics in animals, resulting in lower costs. The adhesives spontaneously lost skin adherence in 7 or 14 days, and they were relatively easy to apply therefore eliminating the demand for expert surgeons. These characteristics have been confirmed by the literature and the use of these substances as a method of wound closing was satisfactory for doctors and patients ${ }^{7,9}$. On the other hand, this study also showed that using CA on the skin had unfavorable effects restricted to local complications especially dehiscence and inflammation. These effects were probably due to specific surgeries and not attributable to properties of the adhesives ${ }^{3,7,22}$. The registered deaths were probably due to anesthetic complications that occurred after the surgery, which was quick (10 min) consisting of a small superficial incision. Necropsies did not show evidence of traumatic wounds or systemic toxicity. The economical differences among the closing methods were remarkable. Each OCA recipient was thoroughly investigated due to its high cost. Although the ECA ( $3 \mathrm{ml}$ ) tube allowed it to be applied in a volume 6 times that of OCA, they were used identically to permit comparisons and minimize infection risks. For sutured incisions, threads were used in large quantities from each purchased unit. The total costs were about $\$ 572$ for OCA, $\$ 81$ for sutures and \$20 for ECA. Thus, ECA cost about 4 and 29 times less than OCA and sutures, respectively. According to our results, epithelization was similar with each wound closure method suggesting that the CAs and sutures affect the epidermis similarly without disrupting its regeneration. Experimental researchers have noticed that in the first $24 \mathrm{~h}$ after surgery epithelization was more complete with sutures than with ECA but they were equivalent by the $72 \mathrm{~h}$ period ${ }^{9}$. The fast polymerization of CAs enables tissues to join early and allows a faster surgical time providing fast keratinized epithelization ${ }^{7}$. Significant levels of dehiscence occurred in the initial cicatrisation periods. We observed that dehiscence appeared early and it was reduced by the natural process of cicatricial retraction so that in the final periods the opening could not be observed; thus, the final product was identical in the three groups. Other reports state that early dehiscence is the second main disadvantage of CA use especially on the extremity of the localized wounds without deep relaxing sutures which oscillate between 0.3 and $26 \%{ }^{7,26}$. According to our experiments, differences in the occurrence of dehiscence at the macroscopic and microscopic levels were attributed to large amounts of histopathological detection. The animal's constant movement, the presence of stitches, scabs, and adhesive pellicles on the wound and the difficulty of measuring openings with the naked eye, was not favorable for the clinical detection of dehiscence. References to deep openings were not found in the literature. This effect was seen as partial dehiscence; the epidermis surface remained humid and formed a bridge on the deep section which, in initial periods, was far, partial (until the dermis), or total (reached the flesh panniculus). In the final periods, the epidermis tended to regress, probably due to fibrosis retraction, but not a result of frank dehiscence or cicatricial widening. The presence of deep openings in all the groups was attributed to the absence of deep relaxing sutures, since studies show that when those are present, dehiscence does not occur ${ }^{26}$. The worst results presented by adhesives were the absence of support in the deepest parts of the incisions, so the cyanoacrilate pellicle was located only on the cutaneous surface. We postulate that in a large series this would not result in cicatricial widening. The highest deep opening occurrence in the OCA closings on the 21st POD was attributed to technical mistakes in the closing or to the small sample size. Positive results concerning reactions to the closing materials were the most irregular and were more prevalent with adhesives than sutures; ECA and OCA produced similar results in this regard. Microscopic analysis showed that in spite of care in application, the CAs penetrated the wound, but did not polymerize inside it. Moreover, the CAs initiated phagocytosis by multinucleus giant cells which completely disappeared one year after surgery ${ }^{11}$. We confirmed that acute inflammatory reactions related to ECA occur primarily on the $5^{\text {th }}$ or $7^{\text {th }}$ PODs and are present in the area adjacent to the adhesives; this reaction is gradually reduced as the acrylate is incorporated into cells ${ }^{6,11}$. In the present research, the highest incidence of acute inflammation was observed with suture usage which was followed by ECA and OCA. The fast contact permanency with CA tissues can explain the inflammation triggered by adhesives compared to sutures from the $7^{\text {th }}$ POD. These initial observations contradicted the findings in the literature that showed important differences in toxicity between ECA and OCA; but the exact toxic effect of ECA was not established. In one study, rats submitted to myocardial repair, and lung and aorta repair using polytetrafluoroethylene patch cuttings which were joined with ECA showed similar necrosis, granulomathosis and inflammatory reactions ${ }^{15}$. In rats, inflammation, tissue granulation, reactions to foreign substances and fibrosis were worse in ECA closings compared to BCA and sutures, although ECA was just as efficient in the final cicatrisation $^{8}$. Other authors demonstrated that when ECA was used to close rats' skin, inferior histological behavior at the suture end was observed after 2, 5 and 10 days. This effect was similar to the $21^{\text {st }}$ day, but the histological standard was better compared to glue with gelatin as a basis ${ }^{10}$. Another study demonstrated that ECA produced more inflammation than BCA with the latter showing persistent reactions to foreign substances, exacerbated fibrosis, seroma and cartilaginous graft rejection applied to rabbits' ears ${ }^{11}$. Compared to MCA, 
ECA caused less infiltration of neutrophils and did not produce necrosis, however the ECA fragments stayed longer than $\mathrm{MCA}^{6}$. A clear relationship between ECA concentration and toxicity was observed, with cell number reducing proportionally as the concentration increased; however, this cytotoxicity was smaller with ECA than $\mathrm{MCA}^{12,17}$. The presence of granulation tissue and fibrosis were similar to what was expected in the normal cicatrisation process with predominant use of ECA. The former were more abundant in the initial periods and then substituted with fibrosis in the final periods. This suggests that fiber collagen deposition was less significant in the final interference when synthetic methods were used. This mechanism can be the main cause of the favorable cosmetic results seen with the scars in the present research which were mostly observed in later periods of cicatrisation. Other studies revealed large formations of granulation tissues in ECA compared to sutures ${ }^{8}$. The fibrotic tissues seem to substitute the degraded polimeric ${ }^{11}$. Several authors have shown that the main disadvantage of ECA and the other CAs is their cytotoxicity. The CAs have been shown to lyse cells in vitro and to cause acute or chronic inflammation in vivo ${ }^{6,11,12}$. The toxicity was primarily attributed to release of toxic metabolites, with small chain derivatives more toxic than the big chain because they are degraded faster. The inflammation intensity triggered by CAs seems to affect the ECAs' tensile strength ${ }^{2,6}$. The toxic effect due to CA use is more noticeable in deep and vascular tissues and has been recommended for use topically on the skin not on vessels surfaces ${ }^{1,3,11}$. In spite of recent advances, the problem persists since the use of any CA is not exempt from risks ${ }^{4,11,17,18,21-23}$. The most favorable result obtained in this study was that necrosis did not occur in any of the animals. The lack of this complication could be due to the correct technical performance of the operation, use of the CAs externally, short contact period with the skin surface, and presence of small quantities of adhesives inside the wound. The toxicity question appeared in doctor's environment with the initial CA application in adhering nerves, tendon, bones, lungs, blood vessels and skin. Other data suggests that necrosis is induced by CAs however these reports were restricted only to the MCA formulation ${ }^{6}$ and cutaneous necrosis is rare. There is one account of skin necrosis in a patient who used commercial ECA without a doctor's recommendation to treat a dried cut in his thumb ${ }^{18}$. Impressively, our results show that complications related to cicatrisation, including infection, necrosis, allergic reactions or scar hypertrophy, were completely absent and, after $21 \mathrm{~d}$, scars formed that did not widen and were acceptable cosmetically. Clinical studies concur that using CAs on skin produced scars with aesthetic aspects similar to intradermic sutures ${ }^{7}$. Consistent with previous studies, the present results strongly suggest that ECA is suitable for use on skin. The low infection indexes of the CAs have been attributed to reduced foreign substances inside the wound. Sutures had increased infection rates due to more contaminated wounds and smaller quantities of contamination necessary to produce infection ${ }^{24}$; allergic reactions were extremely rare $^{20}$.

\section{Conclusion}

Ethyl-cyanoacrylate was well tolerated in this study and did not induce necrosis, allergic reactions or infections, presenting several advantages in relation to octylcyanoacrylat and sutures, including lower costs and fewer complications.

\section{References}

1. Reece TB, Maxey TS, Kron IL. A prospectus on tissue adhesives. Am J Surg. 2001;182:40S-4S.

2. Ninan L, Monahan J, Stroshine RL, Wilker JJ, Shi R. Adhesive strength of marine mussel extracts on porcine skin. Biomaterials. 2003;24:4091-9.

3. Toriumi DM, O’Grady K, Desai D, Bagal A. Use of octyl-2-cyanoacrylate for skin closure in facial plastic surgery. Plast Reconstr Surg. 1998;102:2209-19.

4. Coover HW, Joyner FB, Shearer NH, Wicker TM. Chemistry and performance of cyanoacrylate adhesives. Soc Plast Eng. 1959;15:413-7.

5. Kine BB, Novak RW, Rohm and Haas Company. 2cyanoacrylics ester polymers. In: Encyclopedia of Chemical Technology A to Alkanolamines. 3ed. New York: John Wiley \& Sons, Seaborg; 1978. p. 408-13.

6. Tseng YC, Hyon SH, Ikada Y, Shimizu Y, Tamura K, Hitomi S. In vivo evaluation of 2-cyanoacrylates as surgical adhesives. J Appl Biomater 1990;1:111-9.

7. Singer AJ, Thode HC Jr. A review of the literature on octylcyanoacrylate tissue adhesive. Am J Surg. 2004; 187: 238-48.

8. Borba CC, Roubaud Neto E, Val RLR, Borba Jr CO, Soufen MA, Francisco Neto A, Sakotani AY. Use of cyanoacrylate as surgical adhesive in rats skin incisions: experimental study. Acta Cir Bras. 2000;15: 48-54.

9. Greco Jr JB, Carmo VM, Filho ALL. Uso do 2octilcianoacrilato em síntese tecidual: estudo experimental em camundongos. Rev Soc Bras Cir Plast. 2000;15(2):47-54.

10. Pires MSM. Comparação histológica entre cola à base de gelatina, resorcina e formaldeído (GRF), fio de sutura mononylon e etilcianoacrilato na síntese de ferimentos cirúrgicos produzidos em dorso de ratos [Tese doutorado]. Faculdade de Odontologia da Pontífícia Universidade Católica do Rio Grande do Sul; 2002; 
11. Toriumi DM, Raslan WF, Friedman M, Tardy ME. Histotoxicity of cyanoacrylate tissue adhesives: a comparative study. Arch Otolaryngol Head Neck Surg. 1990;116:546-50.

12. Montanaro L, Arciola CR, Cenni E, Ciapetti G, Savioli S, Filippini F, Barsanti LA. Cytotoxicity, blood compatibility and antimicrobial activity of two cyanoacrylate glues for surgical use. Biomaterials. 2001;22:59-66.

13. Donkerwolcke M, Burny F, Muster D. Tissues and bone adhesives-historical aspects. Biomaterials. 1998;19:1461-6.

14. Gonzalez E, Orta J, Quero C, Niemshik L, Galera R, Onay D, Rojas O. Ethyl 2-cyanoacrylatefixation of the cranial bone flap after craniotomy. Surg Neurol. 2000;53:288-9.

15. Kaplan M, Bozkurt S, Kut MS, Kullu S, Demirtas MM. Histopathological effects of ethyl 2cyanoacrylate tissue adhesive following surgical application: an experimental study. Eur J Cardiothorac Surg. 2004;25:167-72.

16. Samson D, Marshall D. Carcinogenic potential of isobutyl2-cyanoacrylate. J Neurosurg. 1986; 65:571-2.

17.Evans CE, Lees GC, Trail IA. Cytotoxicity of cyanoacrylate adhesives to cultured tendon cells. J Hand Surg. 1999;24:658-61.
18. Wang AA, Martin CH. Full-thickness skin necrosis of the fingertip after application of superglue. J Hand Surg. 2003;28:696-8.

19. Ena P, Mazzarello V, Fenu G, Rubino C. Leukonychia from 2-ethil-cyanoacrylate glue. Contact Dermatites. 2000;42:105-6.

20. Tomb RR, Lepoittevin JP, Durepaire F, Grosshans E. Ectopic contact dermatitis from ethyl cyanoacrylate instant adhesives. Contact Dermatites. 1993;28:206-8.

21. Nakajima N, Nagahiro S, Matsubara, Satoh K. Ruptured de novo thrombotic giant aneurysm induced by ethyl 2-cyanoacrylate: case report. Surg Neurol. 2004;62:346-51.

22.Caloi MT, Manganello-Souza LC. Uso do cianoacrilato no fechamento cutâneo das queiloplastias primárias. Rev Soc Bras Cir Plast. 2005; 20(2):108-11.

23. van den Ende ED, Vriens JH, Allema JH, Breslau PJ. Adhesive bonds or percutaneous absorbable suture for closure of surgical wounds in children: results of a prospective randomized trial. J Pediatr Surg. 2004; 39:1249-51.

24. Quinn J, Maw J, Ramotar K, Wenckenbach G, Wells G. Octylcyanoacrylate tissue adhesive versus suture wound repair in a contaminated wound model. Surg. 1997;122:69-72.

\section{Correspondence:}

Sandro Cilindro de Souza

Rua do Cabral, 18/101

40055-010 Salvador - BA Brazil

sandrocilin@ig.com.br
Conflict of interest: none Financial source: none

Received: January 15, 2007 Review: March 12, 2007 Accepted: April 18, 2007

\section{How to cite this article}

Souza SC, Oliveira WL, Soares DFOS, Briglia CH, Athanázio PR, Cerqueira MD, Guimarães PH, Carreiro MC. Comparative study of suture and cyanoacrylates in skin closure of rats. Acta Cir Bras. [serial on the Internet] 2007 July-Aug;22(4). Available from URL: http://www.scielo.br/acb 